\title{
MJN KNOWLEDGE, ATTITUDE AND PRACTICES TOWARDS COVID-19 OF COMMUNITY IN BENGKULU PROVINCE, INDONESIA
}

\author{
Rina Delfina*, Nurmukaromatis Saleha, Sardaniah Sardaniah \\ Program Studi D3 Keperawatan, University of Bengkulu, Indonesia \\ *Corresponding Author's Email: rdelfina@unib.ac.id
}

\begin{abstract}
Corona Virus (Covid-19) has spread throughout the world, including Indonesia and Bengkulu province. The high spread of cases raises fear and concern in the community, especially those who have not been exposed to clear information about Covid-19. Community understanding and supportive attitudes as well as good preventive measures play an important role in reducing the rate of spread in Bengkulu Province. Effectiveness in reducing the number of cases is very dependent on the cooperation and compliance of the whole community. The purpose of this study was to describe the knowledge, attitudes and practice of the people in Bengkulu Province regarding Covid-19. Methods: This research is a descriptive study with a total sample of 200 people taken by accidental sampling by distributing questionnaires in 10 districts / cities in Bengkulu Province. Results: Among 200 respondents, there were $(86.5 \%)$ good knowledge, $(52.0 \%)$ positive attitudes and $(61.5 \%)$ respondents had good practice in preventing Covid-19. Conclusion: The public knowledge and understanding is important, as well as supportive attitudes in efforts to prevent transmission. Recommendation: It is necessary to disseminate clear and consistent information to all people in Bengkulu Province and its surrounding areas to break the chain of spreading Covid-19.
\end{abstract}

Keywords: Covid-19; Knowledge; Attitude; Practice

\section{INTRODUCTION}

Fear and concern about the transmission of Covid19 raises various problems in community. The corona virus has spread throughout the world including Indonesia. Until now, the transmission of the corona virus continues to occur in the community. The efforts that have been made by the government to break the chain of the spread of the corona virus are by carrying out large-scale social restrictions and reducing group activities in large numbers. In Bengkulu Province itself, the efforts made by the local government are by making regional regulations on the prohibition of holding events that gather large numbers of people, such as weddings, music events in large numbers. Everything the government does will not have an impact on reducing the number of cases exposed to Covid-19 if it is not supported by the cooperation of all levels of community and compliance with regulations made by the government.

Covid-19 transmission can occur through splashing saliva or holding objects in public places that have been affected by the corona virus. Anticipation that can be done to break the chain of the spread of the corona virus is to use masks, wash hands and keep your distance. When a person has contracted the corona virus it can cause problems in the respiratory system which show symptoms of shortness of breath, cough and high fever. The corona virus is a virus that is highly contagious, and can be transmitted to humans and can attack anyone such as babies, children, adults, the elderly, pregnant women, and breastfeeding mothers (Chen et al., 2020). The risk of being exposed to society is quite high if it is not balanced with the delivery of clear information to the public in efforts to prevent Covid-19. The people who are maximum risk of infection are those who have close contact with Covid- 
19 patients or nurses who have direct contact with sufferers (Liang, 2020).

Understanding and supportive attitudes and good practice from the community towards Covid-19 are very important to prevent the transmission of this disease. Infection prevention and control measures can be taken by complying with regulations made by the government (Reuben et al., 2020). Also by wearing a mask, washing your hands and keeping your distance. Good knowledge will increase public understanding of Covid-19 which can be done through counseling, education and consistent information to the public (Delfina et al., 2020).

\section{METHODOLOGY}

This research is a descriptive study, which aims to provide an overview of the knowledge, attitudes and actions of the people in Bengkulu Province regarding Covid-19. The population in this study were people in Bengkulu Province, with a total sample of 200 people who were taken by accidental sampling. The research instrument used a structured questionnaire consisting of three main parts designed to determine knowledge, attitudes and actions which are distributed directly to respondents while maintaining health protocols. The study was conducted from October to November 2020. The data analysis process was carried out using SPSS. The results of the research are presented descriptively in the form of frequency and percentage. This research has passed the ethical test stage from the Faculty of Medicine and Health Sciences, Bengkulu University.

\section{RESULTS}

The description of the characteristics respondents in this study can be seen in table 1 . The average age of the respondents is 34 years, with a minimum age of 13 years and a maximum age of 77 from 200 respondents.

\section{Table 1: Characteristics of Respondents by Age}

\begin{tabular}{|l|c|c|c|c|c|}
\hline Variable & Mean & Median & SD & Min-Max & CI for Mean 95\% \\
\hline Age & 34.11 & 29.00 & 12.985 & $13-77$ & $30.48-34.11$ \\
\hline
\end{tabular}

Table 2 describes the frequency distribution of the characteristics of respondents based on gender, showing $50.5 \%$ of the respondents were male, $52.0 \%$ of respondents had high school education, and $38.5 \%$ of respondents worked as laborers
Table 2: Characteristics of Respondents Based on Gender, Education and Profession

\begin{tabular}{|l|c|c|}
\hline Variable & Frequency (N) & Percentage (\%) \\
\hline Gender & 101 & $50.5 \%$ \\
Man & 99 & $49.5 \%$ \\
Women & & \\
\hline Education & $15.0 \%$ \\
Primary School & 30 & $14.0 \%$ \\
Junior High & 28 & $52.0 \%$ \\
High school & 104 & $19.0 \%$ \\
S1 / S2 / S3 & 38 & \\
Profession & & $7.7 \%$ \\
Civil servants & 15 & $38.5 \%$ \\
Labor & 77 & $27.5 \%$ \\
Farmer & 55 & $0.5 \%$ \\
IRT & 1 & $25.0 \%$ \\
Lecture & 48 & $2.0 \%$ \\
Not yet working & 4 & \\
\hline
\end{tabular}

Table 3 describes the frequency distribution of respondents who have good knowledge $(86.5 \%)$, positive attitudes $(52.0 \%)$ and respondents who have good practice about Covid-19 (61.5\%).

Table 3: Frequency Distribution of Respondents' Knowledge, Attitudes and Practice About Covid-19 in Bengkulu Province

\begin{tabular}{|l|c|c|}
\hline \multicolumn{1}{|c|}{ Variable } & Frequency (N) & Percentage (\%) \\
\hline Knowledge & 173 & $86.5 \%$ \\
Good & 27 & $13.5 \%$ \\
Not good & & \\
\hline Attitude & 104 & $52.0 \%$ \\
Positive & 96 & $48.0 \%$ \\
Negative & & \\
\hline Practice & 123 & $61.5 \%$ \\
Good & 77 & $38.5 \%$ \\
Not good & &
\end{tabular}

\section{DISCUSSION}

This research was conducted at all layers in Bengkulu province. The results showed that the knowledge of the people in Bengkulu province $(86.5 \%)$ was good, directly proportional to the attitudes and practice of the community in preventing Covid-19, it was seen that 173 respondents had good knowledge, 104 respondents had positive attitudes and 123 respondents with good practice against the prevention of Covid-19. Good knowledge is followed by good attitudes and practice in preventing Covid-19. Most of the Bengkulu people already have good knowledge in preventing Covid-19 such as using masks, maintaining distance, and limiting themselves to doing activities outside the home. Likewise with a sufficiently supportive attitude in 
complying with government recommendations in breaking the Covid-19 chain. Good knowledge will encourage positive attitudes (Peng et al., 2020). The results of the same research conducted (Yanti et al., 2020) showed that community cases were in the lowrisk case category $(85.33 \%)$, public knowledge $(70 \%)$ was good, and community behavior showed that they had complied with health protocols during the pandemic Covid-19.

Research (Azlan et al., 2020) in Malaysia also shows that good knowledge, attitudes and actions in taking preventive measures against Covid-19, such as avoiding crowds and washing hands. The results of the study (Yanti et al., 2020) also show that the community has good knowledge of maintaining distance as a way to prevent Covid-19 transmission. Maintaining a distance can break the chain of transmission. According to Lewnard, \& Lo, (2020) from the results of his researchit was seen that the only strategy against Covid-19 is to reduce the mixing of vulnerable people and reduce contact.

Knowledge is a prerequisite for building confidence in prevention, forming positive attitudes, and taking positive practice in preventing the transmission of Covid-19 (McEachan et al., 2016). Most of human knowledge is obtained through education, people's experiences, mass media and the environment (Notoatmodjo, 2012). Knowledge of the Covid-19 disease is very important so as not to cause an increase in the number of cases of Covid-19. Knowledge of Covid-19 patients can be interpreted as the result of knowing from patients about the disease, understanding the disease, ways of prevention, treatment and complications (Mona, 2020). Knowledge plays an important role in determining complete behavior because knowledge will form trust which will then be applied in real life, which becomes the basis for decision making and determining behavior towards certain objects so that it will influence someone's behavior. Public knowledge, especially in preventing the transmission of the spread of Covid-19, is very useful in suppressing transmission of the virus (Law et al., 2020). By having good knowledge of something, a person will have the ability to determine and make decisions on how he can deal with it (Purnamasari et al., 2020). From some of these studies, it can be seen that knowledge is an important aspect that needs to be considered in solving problems, especially related to
Covid-19. The use of masks, maintaining distance, and washing hands frequently are recommended as ways to reduce transmission of Covid-19 around the world. The results of the study (Ahmed et al., 2018) show that maintaining a distance of 3-6 feet (social distancing) can reduce the risk of person-to-person transmission and crowds must be avoided. Social distancing will limit the reproduction rate $(\mathrm{R} 0)$ in the spread of the virus among communities (Aslam, 2020). In the social distancing phase, people are strongly advised to avoid traveling to densely populated areas because they have a high risk of infection (Suppawittaya et al., 2020).

The results of this study indicate that most respondents have a positive attitude towards efforts to prevent the transmission of Covid-19, of the 200 respondents as many as 104 have a positive attitude towards preventing Covid-19, which illustrates that the people in Bengkulu province have a supportive attitude towards efforts to prevent Covid-19 transmission. By applying the behavior of wearing masks, maintaining distance, washing hands with soap or hands sanitizer, reducing activities outside the home the diseases can be controlled. Attitude is a closed response or tendency to do or not do something as a reaction to a stimulus or object (Azwar, 2011). A supportive attitude is formed from a good understanding of something and will be practiced in real life. The results of research (Salman et al., 2020) showed good health professionals in Punjab province of Pakistan attitudes in the prevention of Covid-19 and research on students in China by (Peng et al., 2020) also showed a positive attitude in preventing Covid-19. Research results (Zhang et al., 2020) in Henan, China showed that $89 \%$ of health workers had sufficient knowledge about Covid-19 and $89.7 \%$ had taken the right actions about Covid-19. Apart from the level of knowledge, several risk factors including occupation, experience and job category influence the attitudes and actions of health workers regarding Covid-19.

The community needs more than just information, but also the need to understand the prevention efforts being taken to avoid the transmission of Covid-19. Many factors can influence people's attitudes and actions about Covid-19, one of which is that one's selfcontrol will be important to achieve behavior change. According to Liu et al., (2016) knowledge is important to influence changes in individual behavior obtained through learning. Good knowledge will encourage positive attitudes (Peng et al., 2020), this is shown in 
this study that the percentage of good knowledge is 173 $(86.5 \%)$, followed by positive attitudes $104(52.0 \%)$ and $123(61.5 \%)$ with good action against Covid-19 prevention. Supported by research conducted in Uganda, which showed tht good knowledge, leads to good attitude (Ssebuufu et al., 2020), just as in China, which has good knowledge, has a good attitude in preventing Covid-19 (Peng et al., 2020).

The people in Bengkulu Province have good practice $61.5 \%$ against the prevention of Covid-19 transmission. Research (Paul et al., 2020) in Bangladesh showed that overall results $(33 \%)$ of participants showed good knowledge, $52.4 \%$ showed good attitudes and $44.8 \%$ good practices. Likewise, research by (Reuben et al., 2020) in North-Central Nigeria shows the results that $99.5 \%$ of respondents have good knowledge (99.5\%) about Covid-19 obtained through the internet / social media $(55.7 \%)$ and Television (27.5\%). The majority of respondents $(79.5 \%)$ had a positive attitude towards compliance with government regulations in infection prevention and control. About $92.7 \%, 96.4 \%$ and $82.3 \%$ practicing social distancing, improving personal hygiene and use a face mask. The results of Reuben et al., (2020) showed that there is a significant relationship between knowledge and attitudes towards Covid-19 preventive measures.

\section{CONCLUSION}

Good knowledge will influence the way people behave and practice in an effort to break the chain of spreading Covid-19. The more clearer the information received by the public the more will public understanding of prevention efforts against Covid-19. Understanding people's knowledge, attitudes and practice can help policy makers make informed decisions. The need for support from all communities in breaking the Covid-19 chain by following health protocols and complying with policies government policies.

\section{Conflict of Interest}

The authors declare that they have no conflict of interest.

\section{ACKNOWLEDGEMENT}

The authors are thankful to the institutional authority University of Bengkulu for completion of the work.

\section{REFERENCES}

Ahmed, W., Zhang, Q., Lobos, A., Senkbeil, J., Sadowsky, M.J., Harwood, V.J., Saeidi, N., Marinoni, O., \& Ishii, S. (2018). Precipitation influences pathogenic bacteria and antibiotic resistance gene abundance in storm drain outfalls in coastal sub-tropical waters. Environment International, 116, 308-318.

Azwar, S. (2011). Sikap Manusia Teori dan Pengukurannya, Edisi ke-2. Yogyakarta: Pustaka Pelajar Offset.

Azlan, A.A., Hamzah, M.R., Sern, T.J., Ayub, S.H., \& Mohamad E. (2020). Public knowledge, attitudes and practices towards COVID-19: A cross-sectional study in Malaysia. PLoS ONE, 15(5): e0233668. https://doi.org/10.1371

Aslam, F. (2020). COVID-19 and Importance of Social Distancing. Preprints, 30(1), 1-6. https://doi.org/ 10.20944 preprints20200.

Chen, N., Zhou, M., Dong, X., Qu, J., Gong, F., Han, Y., Qiu, Y., Wang, J., Liu, Y., Wei, Y., \& Yu, T. (2020). Epidemiological and clinical characteristics of 99 cases of 2019 novel coronavirus pneumonia in Wuhan, China: a descriptive study. The Lancet, 395(10223), 507-513.

Delfina, R., Saleha, N., \& Salamah, U. (2020). Komunikasi, edukasi dan informasi: upaya peningkatan kesehatan masyarakat beresiko tinggi terhadap penyebaran virus covid-19 di panti sosial tresna werda (pstw) kota bengkulu. Community Development Journal: Journal Pengabdian Masyarakat, 1(3), 511-513.

Law, S., Leung, A. W., \& Xu, C.,2020. Severe acute respiratory syndrome (SARS) and coronavirus disease-2019 (COVID-19): From causes to preventions in Hong Kong. International Journal of Infectious Diseases, 94, 156-163. https://doi.org/10.1016/j.ijid.2020.03.059

Lewnard, J. A., \& Lo, N. C. (2020). Scientific and ethical basis for social-distancing interventions against COVID-19. The Lancet Infectious Diseases, 20(6), 631-633. 
Liang, T. (2020). Handbook of COVID-19 prevention and treatment. The First Affiliated Hospital, Zhejiang University School of Medicine. Compiled According to Clinical Experience, 68.

Liu, L., Liu, Y.P., Wang, J., An, L.W., \& Jiao, J.M. (2016). Use of a knowledge-attitude-behaviour education programme for Chinese adults undergoing maintenance haemodialysis: Randomized controlled trial. Journal of International Medical Research, 44(3), 557-568. doi: 10.1177/0300060515604980

McEachan, R., Taylor, N., Harrison, R., Lawton, R., Gardner, P., \& Conner, M., (2016). Meta-analysis of the reasoned action approach (RAA) to understanding health behaviors. Annals of Behavioral Medicine, 50(4), 592-612.

Mona, N. (2020) Konsep Isolasi Dalam Jaringan Sosial Untuk Meminimalisasi Efek Contagious (Kasus Penyebaran Virus Corona Di Indonesia). Journal Sosial Humaniora Terapan, 8(2), 117-25.

Notoatmodjo, S., (2012). Promosi Kesehatan dan Perilaku Kesehatan. Jakarta: Rineka Cipta.

Paul, A., Sikdar, D., Hossain, M.M., Amin, M.R., Deeba, F., Mahanta, J., Jabed, M.A., Islam, M.M., Noon, S.J., \& Nath, T.K. (2020). Knowledge, attitudes, and practices toward the novel coronavirus among Bangladeshis: Implications for mitigation measures. PloS one, 15(9), e0238492.

Peng, Y., Pei, C., Zheng, Y., Wang, J., Zhang, K., Zheng, Z., \& Zhu, P. (2020). A cross-sectional survey of knowledge, attitude and practice associated with COVID-19 among undergraduate students in China. BMC Public Health, 20(1), 1-8.

Purnamasari, Ika., \& Raharyani, A. E. (2020). Tingkat Pengetahuan Dan Perilaku Masyarakat Kabupaten Wonosobo Tentang Covid-19. Journal Ilmiah Kesehatan, 10(1), 33-42.

Reuben, R. C., Danladi, M. M., Saleh, D. A., \& Ejembi, P. E. (2021). Knowledge, attitudes and practices towards COVID-19: an epidemiological survey in North-Central Nigeria. Journal of Community Health, 46(3), 457-470.

Salman, M., Mustafa, Z., Asif, N., Zaidi, H.A., Shehzadi, N., Khan, T.M., Saleem, Z., \& Hussain, K. (2020). Knowledge, attitude and preventive practices related to COVID-19 among health professionals of Punjab province of Pakistan. The Journal of Infection in Developing Countries, 14(07), 707-712.

Suppawittaya, P., Yiemphat, P., \& Yasri, P. (2020). Effects of Social Distancing, Self-Quarantine and Self-Isolation during the COVID-19 Pandemic on People's Well-Being, and How to Cope with It. International Journal of Science and Healthcare Research, 5(2), 12-20.

Ssebuufu, R., Sikakulya, F., Binezero, S.M., Wasingya, L., Nganza, S.K., Ibrahim, B., \& Kyamanywa, P. (2020). Awareness, knowledge, attitude and practice towards measures for prevention of the spread of COVID-19 in the Ugandans: A nationwide online cross-sectional Survey. Medrxiv.

Wong Zhou, MD. (2020). Handbook of Covid-19 Prevention and Treatment.

Yanti, N.P.E.D., IMADP, N., Wisnawa, G.A., Agustina, N.P.D., \& Diantari, N.P.A. (2020). Gambaran Pengetahuan Masyarakat tentang Covid-19 dan Perilaku Masyarakat di Masa Pandemi Covid-19. J Keperawatan Jiwa, 8(3), 485-90.

Yanti, B., Wahyudi, E., Wahiduddin, W., Novika, R.G.H., Arina, Y.M.D.A., Martani, N.S., \& Nawan, N. (2020). Community knowledge, attitudes, and behavior towards social distancing policy as prevention transmission of COVID-19 in indonesia. Journal Administrasi Kesehatan Indonesia, 8(2), 4-14.

Zhang, M., Zhou, M., Tang, F., Wang, Y., Nie, H., Zhang, L., \& You, G. (2020). Knowledge, attitude, and practice regarding COVID-19 among healthcare workers in Henan, China. Journal of Hospital Infection, 105(2), 183-187. 